\title{
Assessing Barriers Faced by Surgeons While Providing Surgical Care During the COVID-19 Pandemic in Pakistan: An Online Cross-Sectional Study
}

This article was published in the following Dove Press journal:

Journal of Multidisciplinary Healthcare

\author{
Abdul Majeed (D) \\ Iltaf Hussain (1D) \\ Imran Imran ${ }^{2}$ \\ Muhammad Usman Saleem ${ }^{3}$ \\ Hamid Saeed (D) ${ }^{4}$ \\ Muhammad Asad Abrar \\ Muhammad Islam ${ }^{4}$ \\ Furqan K Hashmi (iD ${ }^{4}$ \\ Muqarrab Akbar ${ }^{5}$ \\ Basit Ramzan ${ }^{6}$ \\ Muhammad Omer Chaudhry \\ Waseem Ashraf ${ }^{2}$ \\ Muhammad F Rasool (iD) \\ 'Department of Pharmacy Practice, \\ Faculty of Pharmacy, Bahauddin Zakariya \\ University, Multan, Pakistan; \\ ${ }^{2}$ Department of Pharmacology, Faculty of \\ Pharmacy, Bahauddin Zakariya University, \\ Multan, Pakistan; ${ }^{3}$ Department of \\ Biosciences, Faculty of Veterinary \\ Sciences, Bahauddin Zakariya University, \\ Multan, Pakistan; ${ }^{4}$ University College of \\ Pharmacy, University of the Punjab, \\ Allama Iqbal Campus, Lahore, Pakistan; \\ ${ }^{5}$ Department of Political Science, \\ Bahauddin Zakariya University, Multan, \\ Pakistan; ${ }^{6}$ Al Shifa Pharmacy, Multan, \\ Pakistan; ${ }^{7}$ School of Economics, \\ Bahauddin Zakariya University, Multan, \\ Pakistan
}

Correspondence: Muhammad F Rasool Department of Pharmacy Practice, Faculty of Pharmacy, Bahauddin Zakariya University, Multan, 60800, Pakistan Tel +923008639046

Email fawadrasool@bzu.edu.pk
Background: The COVID-19 pandemic is not only affecting public health, but it is also impairing the specialized surgical care services in the hospitals. The present study aimed to assess the barriers faced by the surgeons while performing surgical procedures during the COVID-19 pandemic.

Methods: A cross-sectional, web-based survey was conducted from September 10 to October 14, 2020. The study population consisted of surgeons practicing in Kpk, Pakistan. Descriptive statistics and binary logistic regression analysis were used to analyze the data.

Results: A total of 292, out of 543, surgeons participated in the study (response rate: $59.6 \%$ ). The younger surgeons (25-30 years) considered the lack of policies and practices regarding exposure to COVID-19 patients as a significant barrier to their practice. The surgeons practicing in private hospitals considered themselves at a higher risk while providing surgical care to the COVID-19 patients. The non-cooperation of the patients was the main barrier in delivering surgical care services.

Conclusion and Recommendation: The current study highlighted the barriers to the surgeons while providing surgical care to patients in the current pandemic. The most pronounced barriers to the surgeons were the lack of policies regarding exposure to COVID-19 and practice and non-cooperation of the patient. To address these barriers, it is recommended that health regulatory agencies of Pakistan should implement strict infection control practices to ensure the safety of surgeons and allied healthcare staff during the COVID-19 pandemic.

Keywords: COVID-19, nCoV-2, surgeons, barriers

\section{Introduction}

The current pandemic of coronavirus disease-19 (COVID-19) is deteriorating the health and social wellbeing globally. ${ }^{1}$ Several outbreaks have been reported in recent decades, such as the outbreak of severe acute respiratory syndrome coronavirus (SARS-COV) in $2003,{ }^{2}$ an influenza pandemic (H1N1) in $2009,{ }^{3}$ Middle East respiratory syndrome (MERS-CoV) in 2012, ${ }^{4}$ and Ebola virus disease in 2014-2016, ${ }^{5}$ that had greatly affected the global healthcare system.

During the COVID-19 pandemic, the hospitals have become a hot zone for the treatment and transmission of this disease. ${ }^{6}$ The health care workers (HCWs) are at a higher risk for contracting this disease and if appropriate preventive measures are 
not taken, the HCWs can be severely affected by this pandemic. ${ }^{7}$ The COVID-19 pandemic is not only affecting public health, but it is also impairing the specialized surgical care services in the hospitals. The surgery departments in the hospitals are providing elective and emergency surgery services to the patients round the clock. $^{1,8}$ The operation theaters (OT) are the high-risk areas for transmission of COVID-19. ${ }^{9}$ Several patients were deprived of routine surgical procedures during the rapid rise period of COVID-19, as the routine surgical care services were suspended by the health administration. The lack of the COVID-19 specific preventive practices in the surgical departments of the hospitals may cause the spread of COVID-19, which can ultimately lead to subsequent waves of this infection. ${ }^{10}$

Pakistan is a middle-income country with a weak healthcare infrastructure and a population of 220 million, which makes it vulnerable to subsequent waves of COVID-19. ${ }^{11}$ In August 2020, there was a short decline in confirmed COVID-19 cases in Pakistan. Currently, the number of COVID-19 cases are on the rise in Pakistan, which may be the sign of a second wave. As of October 10, 2020, the total number of confirmed COVID-19 cases in Pakistan was 320,463 with a death toll of $6601 .{ }^{12}$ During the current COVID-19 outbreak in Pakistan, the lack of appropriate infection control practices in the healthcare facilities has resulted in the deaths of many HCWs. ${ }^{13}$ Till October 14, 2020, 32,937 HCWs were diagnosed with COVID-19, and the associated deaths were 733. ${ }^{12,13}$

To ensure the safety of HCWs in Pakistan, the policymakers should adopt and implement International guidelines for preventing the spread of COVID-19 in healthcare facilities. The surgeons and their supporting staff are equally exposed to COVID-19, as they are performing often emergency surgeries in uncertain emergency circumstances, where the patient's COVID-19 status is unknown. Several recommendations and directories have been reported that are focused on preventing the transmission of COVID-19 to surgeons while performing different procedures. American College of Surgeons (ACS) has recommended that during the COVID-19 pandemic, the hospitals and surgery centers should prioritize patient's needs regarding the surgical procedures. ${ }^{14}$ Royal College of Surgeons of England (RCS) stated that all surgeons and teams must familiarize themselves with appropriate infection control practices and must ensure that they have access to the right personnel protective equipment
(PPE). ${ }^{15}$ In Pakistan, various guidelines have been issued by the Ministry of National Health Services Regulations and Coordination (NHSRC) ${ }^{16}$ for the safety of the HCWs, but there are no COVID-19 guidelines that are specific to the surgeons.

In Pakistan, there is no previous report of a study that was focused on assessing the barriers faced by the surgeons while performing different surgical procedures during the COVID-19 pandemic. Therefore, if such a study is conducted, it can assist the health administration and the policymakers in devising guidelines related to handling of COVID-19 patients during the surgical procedures, which can ultimately help in preventing the transmission of this infection among the surgeons and other HCWs while engaging COVID-19 suspected or confirmed cases. Hence, the present study was conducted to assess the barriers faced by the surgeons while performing surgical procedures during the COVID-19 pandemic in Khyber Pakhtunkhwa (Kpk) province, Pakistan.

\section{Materials and Methods}

\section{Study Design, Period, and Population}

A cross-sectional web-based survey was conducted from September 10 to October 14, 2020. The study population consisted of surgeons practicing in KpK, Pakistan. Only practicing surgeons in Kpk, Pakistan were included in the study.

\section{Development and Validation of the} Instrument

A survey instrument was designed based on the Center for Disease Control and Prevention (CDC) guidelines. ${ }^{17}$ An initial draft of the questionnaire was designed and subsequently validated in two steps. Firstly, the study instrument was sent to researchers and professionals from medical backgrounds (pharmacists and doctors) to give their expert opinion for its simplicity, relativity, and importance. Secondly, a pilot study was conducted on a small sample of Surgeons $(\mathrm{N}=22)$ for their opinions on making the questionnaire simpler and shorter. The questionnaire reliability was assessed by using Statistical Package for the Social Sciences (SPSS) Version 25 (IBM Corp., Armonk, NY, USA). The Cronbach's alpha value of 0.74 was obtained, which indicated that our questionnaire was internally consistent. The data from the pilot study was not used in the final analysis. 
The questionnaire consisted of two parts, the first part consisted of demographic characteristics, including information related to the gender, age, hospital, residence, and experience of dealing with COVID-19 patients. The second part comprised of 12 items that were used to assess the barrier to surgeons. All the questions were answered on a "yes" or "no" basis. The study questionnaire can be seen in Supplementary Table S1.

\section{Survey Administration and Data Collection}

The Checklist for Reporting Results of Internet E-Surveys (CHERRIES) guideline was followed for online survey administration and data collection. ${ }^{18}$ An online questionnaire was designed using Google forms (Google LLC. USA) and its online link was shared, based on the author's source, through various social media platforms such as WhatsApp, Facebook, and E-mail. The participants could view the question by simply clicking on the shared link and answer the questions. The first page of the questionnaire comprised of short introduction regarding the objectives, procedures, declaration of confidentiality and anonymity, and the volunteer nature of the participation. To avoid redundant responses, all questionnaires were excluded from the final analysis that was submitted too soon (less than 1 minute). To prevent multiple entries, a closed survey technique was used. The responses were collected using google forms and only completed questionnaires (with answers to all the questions), were included in the final analysis. The questionnaire took 4-6 min to complete. The data collection process can be seen in Figure 1.

\section{Ethical Approval and Consent to Participate}

This study was performed in accordance with the Declaration of Helsinki and was approved by the ethical committee of the Department of Pharmacy Practice, Faculty of Pharmacy, Bahauddin Zakariya University, Multan, Pakistan (Reference No: Acad/PRAC/18-20/22). The study questionnaire contained an informed consent section that stated the purpose of the study, the nature of the survey, study objectives, voluntary participation, declaration of confidentiality, and anonymity. The work has been reported in line with Strengthening the reporting of cohort studies in surgery (STROCSS) criteria (Supplementary Information: STROCSS Checklist). ${ }^{19}$

\section{Statistical Analysis}

The statistical analysis was performed using SPSS version 25.0 (IBM SPSS Statistics, New York, United States). Descriptive statistics were used to summarize the data as a frequency and percentage. A binary logistic regression analysis was performed to identify the possible determinants of barriers with the results expressed as odds ratio (OR), 95\% CI, and P-value. The applied statistical tests were two-tailed and a P-value of $<0.05$ was considered statistically significant.

\section{Results}

A total of 292, out of 543, surgeons participated in the study (response rate: 59.6\%), amongst which, 187 (64\%) were male and $105(36 \%)$ were female. Most of the participants were from the age range of 25-30 years (57.4\%) and more than half of the surgeons were practicing in the government sector (59.2\%). Most of the surgeons were engaged with COVID-19 patients (68.5\%). The demographic details for the study participants are provided in Table 1.

The most prominent barriers, related to facility, pointed out by the participants were lack of separate surgical room for engaging COVID-19 positive or suspected patients (86.6\%), lack of task-specific education and training programs (54.8\%), and unavailability of complete PPEs (38.4\%). Moreover, the barriers related to surgeon's knowledge, risk perception, and their support staff were considering themselves at high risk in the current pandemic (85.3\%) and insufficient and less skillful supportive staff while dealing with COVID-19 positive or suspected patients (38.7\%). Furthermore, the participants highlighted the barriers related to patients including lack of cooperation by the patients $(72.4 \%)$ and the overcrowding by patients or their relatives in the emergency room as a barrier in the infection control practice $(91.1 \%)$. The barriers related to surgeons can be seen in Table 2 .

The binary logistic regression analysis demonstrated that the younger surgeons (age range of 25-30 years) considered the lack of policies and practices regarding exposure to COVID-19 patients as a significant barrier to their practice [OR (95\% CI): 2.6 (1.5-2.4), P-value $<0.001]$. Moreover, the lack of task-specific education and training programs for the prevention of COVID-19 infection in hospitals was a significant barrier to the male surgeons [OR (95\% CI): 3.7 (2.2-6.2), P-value $<0.001]$. The lack of infection control policies and 
practices was a significant barrier towards performing surgical procedures in the private hospitals [OR $(95 \%$ CI): 1.9 (1.01-3.8), P-value $<0.001]$ and unavailability of complete PPEs [OR (95\% CI): 3.5 (2.0-5.9), P-value $<0.001]$. The detail of facility-related barriers can be seen in Supplementary Table S2.

The knowledge of male surgeons was poor regarding standard procedure for dealing with COVID-19 patients [OR (95\%cCI): 4.3 (2.2-8.4), P-value $<0.001]$. The surgeons practicing in private hospitals considered themselves at a higher risk while providing surgical care to the COVID19 patients [OR (95\% CI): $2.2(1.1-4.4), \mathrm{P}$-value $=0.014]$. The surgeons that had experience of dealing with COVID-19 patients showed good knowledge regarding infection control practices [OR (95\% CI): $4.3(2.1-8.8), \mathrm{P}$-value $=0.004]$. The barriers related to the surgeon's knowledge and their supporting staff can be seen in Supplementary Table S3.

The younger surgeons considered the overcrowding in emergency areas as a significant barrier to infection control practices [OR $(95 \% \mathrm{CI}): 2.5(0.9-6.4), \mathrm{P}$-value $=0.05$ ] and the general surgeons considered the non-cooperation of the patients as a barrier in delivering surgical care services [OR (95\% CI): 4.5 (2.3-8.9), P-value $<0.001)$. The barriers related to patients can be seen in Supplementary Table S4.

The barriers perceived by the female surgeons were related to policies and practices adopted by the facility $(\mathrm{p}=$ $0.006)$ and to the task-specific education by the facility $(\mathrm{p}=$ 0.001) as shown in Supplementary Table S5.

\section{Discussion}

To the best of our knowledge, this is the first study from Pakistan that has assessed the barriers faced by surgeons while providing surgical services to the COVID-19 patients. The highlighted barriers perceived by the participants were lack of separate surgical rooms, lack of taskspecific education and training programs, and unavailability of complete PPEs. Moreover, the participants considered themselves at high risk in the current pandemic and there was insufficient and less skillful supportive staff in the hospitals. Furthermore, the lack of cooperation by the patients and overcrowding of patients or their relatives in the emergency services was considered a barrier in preventing COVID-19 transmission.

The surgical care practices have been changed in the COVID-19 pandemic, as it has been recommended by the CDC to postpone the elective surgeries and shift inpatients diagnostic and surgical services to outpatient settings where appropriate. ${ }^{20}$ The German Society of Surgery has recommended that surgical care to the COVID-19 positive patients should be provided in separate surgical and treatment rooms. ${ }^{21}$ It is worth mentioning here that in the developed countries, the healthcare authorities have made special arrangements for the provision of surgical care to the COVID-19 patients. But in contrast, it was seen in our study that the lack of a separate surgical room was a major barrier to the surgical care services. Since Pakistan is a lower-middleincome country ${ }^{22}$ and there are limited resources available for health services, ${ }^{23}$ therefore it is not easy for the health administration to assign a separate space for emergency surgical services during the COVID-19 pandemic.

Task-specific education and training regarding preventing transmission of COVID-19 infection can strengthen the healthcare system to preserve and protect the surgeons from being infected in the current pandemic. ${ }^{24}$ The lack of task-specific education and training increases the exposure of surgeons to COVID-19 infection, which was identified as a barrier to the delivery of surgical care to patients in the current study.

It has been made compulsory by the health regulatory agencies to use appropriate PPE to ensure the safety of the surgeons while providing surgical care to the patients in the COVID-19 pandemic. ${ }^{17,20,21}$ In the current study, $38.4 \%$ of the participants were not facilitated with complete PPEs. The unavailability of the complete PPEs may be due to the limited health resources in Pakistan.

The SARS-CoV 2 can be transmitted mainly by respiratory droplets through person-to-person contact and by fecal-oral route. ${ }^{25}$ Since the surgeons are in direct contact with the COVID-19 confirmed or suspected patients while providing surgical care, therefore the surgeons considered themselves at a higher risk for getting the infection in the current study. It is important to maintain a balance between adequate provision of surgical services and preventing transmission along with judicious use of resources. ${ }^{26}$

In the current study, the lack of patient cooperation and overcrowding by patients or their relatives in the emergency room was considered as a barrier towards the control of COVID-19. A social distance up to six feet is considered a major safety measure in controlling the spread of the COVID-19, ${ }^{27}$ but due to overcrowding of patients and their relatives, these safety measures cannot be maintained, which increases the risk of virus transmission. To decrease the chances of virus transmission from 

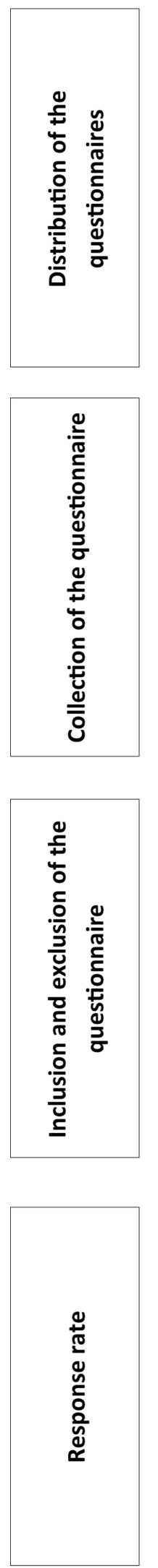

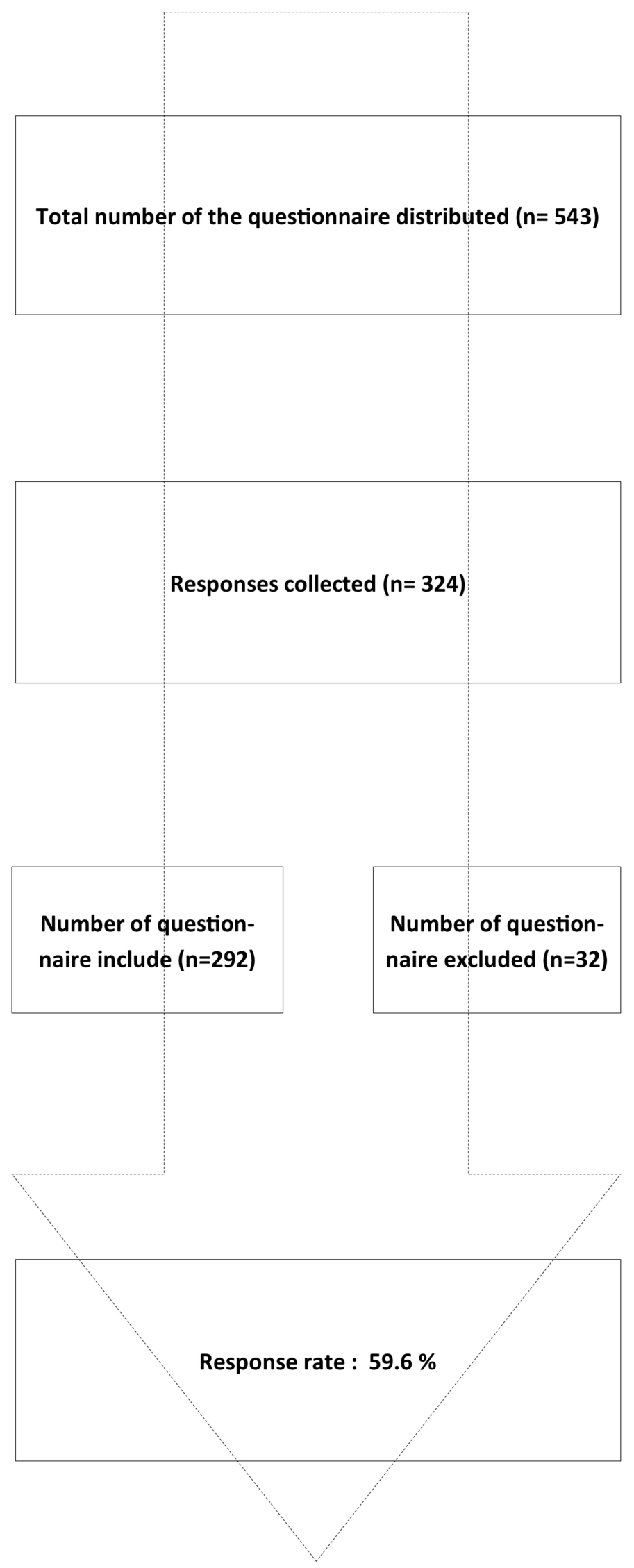

Figure I The adopted strategy for the data collection. 
Table I Demographic Characteristics of the Participants

\begin{tabular}{|c|c|c|c|}
\hline & & $\begin{array}{l}\text { Frequency } \\
\text { (n) }\end{array}$ & $\begin{array}{l}\text { Percentage } \\
\text { (\%) }\end{array}$ \\
\hline Age & $\begin{array}{l}25-30 \\
>30\end{array}$ & $\begin{array}{l}172 \\
120\end{array}$ & $\begin{array}{l}58.9 \% \\
41.1 \%\end{array}$ \\
\hline Gender & $\begin{array}{l}\text { Male } \\
\text { Female }\end{array}$ & $\begin{array}{l}187 \\
105\end{array}$ & $\begin{array}{l}64.0 \% \\
36.0 \%\end{array}$ \\
\hline Practicing hospital & $\begin{array}{l}\text { Private sector } \\
\text { Public sector }\end{array}$ & $\begin{array}{l}119 \\
173\end{array}$ & $\begin{array}{l}40.8 \% \\
59.2 \%\end{array}$ \\
\hline Specialty & $\begin{array}{l}\text { General } \\
\text { surgeon } \\
\text { Orthopedic } \\
\text { surgeon } \\
\text { Neurosurgeon } \\
\text { Others }\end{array}$ & $\begin{array}{l}122 \\
45 \\
24 \\
101\end{array}$ & $\begin{array}{l}41.8 \% \\
15.4 \% \\
8.2 \% \\
34.6 \%\end{array}$ \\
\hline $\begin{array}{l}\text { Experience of } \\
\text { practicing }\end{array}$ & $\begin{array}{l}<1 \text { year } \\
1-5 \text { years } \\
>5 \text { years }\end{array}$ & $\begin{array}{l}82 \\
125 \\
85\end{array}$ & $\begin{array}{l}28.1 \% \\
42.8 \% \\
29.1 \%\end{array}$ \\
\hline $\begin{array}{l}\text { Practicing hospital } \\
\text { locality }\end{array}$ & $\begin{array}{l}\text { Bunnu } \\
\text { Karak } \\
\text { Kohat } \\
\text { Peshawar } \\
\text { Charsadda } \\
\text { Mardan } \\
\text { Swat }\end{array}$ & $\begin{array}{l}27 \\
16 \\
26 \\
175 \\
24 \\
6 \\
18\end{array}$ & $\begin{array}{l}9.2 \% \\
5.5 \% \\
8.9 \% \\
59.9 \% \\
8.2 \% \\
2.1 \% \\
6.2 \%\end{array}$ \\
\hline $\begin{array}{l}\text { Residence } \\
\text { Did you deal } \\
\text { COVID-19 patients }\end{array}$ & $\begin{array}{l}\text { Urban } \\
\text { Rural } \\
\text { Yes } \\
\text { No }\end{array}$ & $\begin{array}{l}142 \\
150 \\
200 \\
92\end{array}$ & $\begin{array}{l}48.6 \% \\
51.4 \% \\
68.5 \% \\
31.5 \%\end{array}$ \\
\hline
\end{tabular}

Note: Others - plastic surgeons, oral and maxillofacial surgeons, ear, nose, and throat (ENT) surgeons, head and neck surgeons.

patient to surgeon, strict infection control measures should be taken. These measures include administrative control measures (ACM), environmental control measures (ECM), and the use of PPE (N95 masks, gloves, goggles, sanitizer, and isolation gown). The ACM includes, developing policies and procedures, implementing protocols, and providing health education and training. The ECM includes ensuring proper ventilation, establishing air-born infection isolation and negative pressure rooms, developing systems for cleaning, and disposal of waste material. PPE is generally ranked lowest in the infection control hierarchy. ${ }^{25}$ However, the PPE is the most important preventive measure during the early stage of the outbreak when drugs, vaccines, or other control measures are not available.
Table 2 The Frequencies and Percentages of Responses of the Participants

\begin{tabular}{|c|c|c|c|}
\hline & & $\begin{array}{l}\text { Frequency } \\
\text { (n) }\end{array}$ & $\begin{array}{l}\text { Percentage } \\
\text { (\%) }\end{array}$ \\
\hline \multicolumn{4}{|l|}{ Barriers related to facility } \\
\hline \multirow{2}{*}{$\begin{array}{l}\text { Does your facility have } \\
\text { policies and practices to } \\
\text { minimize the chance of } \\
\text { exposure to the COVID-19 } \\
\text { virus? }\end{array}$} & Yes & 197 & 67.5 \\
\hline & No & 95 & 32.5 \\
\hline \multirow{2}{*}{$\begin{array}{l}\text { Does your facility have } \\
\text { a separate surgical room for } \\
\text { COVID-19 positive or } \\
\text { suspected patients }\end{array}$} & Yes & 39 & 13.4 \\
\hline & No & 253 & 86.6 \\
\hline \multirow{2}{*}{$\begin{array}{l}\text { Does your facility have } \\
\text { policies and procedures to } \\
\text { restrict visitors from entering } \\
\text { to isolated surgical room? }\end{array}$} & Yes & 226 & 77.4 \\
\hline & No & 66 & 22.6 \\
\hline \multirow{2}{*}{$\begin{array}{l}\text { Does your facility permit sick } \\
\text { leaves upon exposure to } \\
\text { novel coronavirus } 2019 \\
\text { (nCoV-19) }\end{array}$} & Yes & 227 & 77.7 \\
\hline & No & 65 & 22.3 \\
\hline \multirow{2}{*}{$\begin{array}{l}\text { Does your facility have task- } \\
\text { specific education and training } \\
\text { programs on preventing } \\
\text { transmission of infectious } \\
\text { agents before caring for } \\
\text { a patient? }\end{array}$} & Yes & 132 & 45.2 \\
\hline & No & 160 & 54.8 \\
\hline \multirow{2}{*}{$\begin{array}{l}\text { Did you facilitate with } \\
\text { complete personal protective } \\
\text { equipment }\end{array}$} & Yes & 180 & 61.6 \\
\hline & No & 112 & 38.4 \\
\hline \multicolumn{4}{|c|}{$\begin{array}{l}\text { Barriers related to the surgeon's knowledge, and their } \\
\text { support staff }\end{array}$} \\
\hline \multirow{2}{*}{$\begin{array}{l}\text { Do you have complete } \\
\text { knowledge about standard } \\
\text { protocols and procedures for } \\
\text { dealing with COVID-19 } \\
\text { known or suspected patients? }\end{array}$} & Yes & 213 & 72.9 \\
\hline & No & 79 & 27.1 \\
\hline \multirow{2}{*}{$\begin{array}{l}\text { Did you considered yourself } \\
\text { at high risk during dealing } \\
\text { with patients in the current } \\
\text { pandemic situation }\end{array}$} & Yes & 249 & 85.3 \\
\hline & No & 43 & 14.7 \\
\hline \multirow{2}{*}{$\begin{array}{l}\text { Does supportive staff provide } \\
\text { complete support while } \\
\text { engaging with COVID-19 } \\
\text { known or suspected patient }\end{array}$} & Yes & 193 & 66.1 \\
\hline & No & 99 & 33.9 \\
\hline
\end{tabular}

(Continued) 
Table 2 (Continued).

\begin{tabular}{|c|c|c|c|}
\hline & & $\begin{array}{l}\text { Frequency } \\
\text { (n) }\end{array}$ & $\begin{array}{l}\text { Percentage } \\
\text { (\%) }\end{array}$ \\
\hline \multirow{2}{*}{$\begin{array}{l}\text { Do you have sufficient and } \\
\text { skillful supportive staff while } \\
\text { dealing with COVID-19 } \\
\text { suspected or known patients }\end{array}$} & Yes & 179 & 61.3 \\
\hline & No & 113 & 38.7 \\
\hline \multicolumn{4}{|c|}{ Barriers related to patients and their caregivers } \\
\hline \multirow{2}{*}{$\begin{array}{l}\text { Does COVID-19 suspected } \\
\text { or known patient provide } \\
\text { complete cooperation? }\end{array}$} & Yes & 79 & 27.6 \\
\hline & No & 207 & 72.4 \\
\hline \multirow{2}{*}{$\begin{array}{l}\text { Overcrowding by patients or } \\
\text { its relative in Emergency } \\
\text { rooms is a barrier in } \\
\text { infectious control practice? }\end{array}$} & Yes & 266 & 91.1 \\
\hline & No & 26 & 8.9 \\
\hline
\end{tabular}

\section{Limitations}

There are several limitations in this study that cannot be neglected. Firstly, all the responses collected in this study were from an online web-based survey that could have led to selection bias. Moreover, the respondents were from only one province of Pakistan and the study results cannot be generalized to the whole country.

\section{Conclusion and Recommendation}

The current study highlighted the barriers to the surgeons while providing surgical care to patients in the current pandemic of COVID-19. To address these barriers, it is recommended that the health regulatory authorities of Pakistan should implement and supervise the taskspecific education and training programs regarding COVID-19 and should ensure the availability of PPEs to the surgeons and their support staff. To minimize the chance of transmission of the COVID-19, it is recommended that the infection control practices should be implemented as per WHO guidelines.

\section{Institutional Review Board Statement}

This study was performed in accordance with the Declaration of Helsinki and was approved by the ethical committee of the Department of Pharmacy Practice, Faculty of Pharmacy, Bahauddin Zakariya University, Multan, Pakistan (Reference No: Acad/PRAC/18-20/22). The study questionnaire contained a consent section that stated the purpose of the study, the nature of the survey, study objectives, voluntary participation, declaration of confidentiality, and anonymity.

\section{Informed Consent Statement}

Informed consent was obtained from all the subjects participated in the study.

\section{Acknowledgments}

The authors are thankful to the respected surgeons for their kind cooperation.

\section{Author Contributions}

All authors made a significant contribution to the work reported, whether that is in the conception, study design, execution, acquisition of data, analysis and interpretation, or in all these areas; took part in drafting, revising, or critically reviewing the article; gave final approval of the version to be published; have agreed on the journal to which the article has been submitted; and agree to be accountable for all aspects of the work.

\section{Disclosure}

The authors declare no conflicts of interest.

\section{References}

1. Søreide K, Hallet J, Matthews JB, et al. Immediate and long-term impact of the COVID-19 pandemic on delivery of surgical services. $\mathrm{Br}$ $J$ Surg. 2020;107(10):1250-1261. doi:10.1002/bjs.11670

2. World Health Organization. Summary of probable SARS cases with onset of illness from 1 November 2002 to 31 July 2003; 2003. Available from: http://www.who.int/csr/sars/country/table2004_04_ 21/en/index.html. Accessed October 24, 2020.

3. World Health Organization. Emergencies preparedness, response. Pandemic (H1N1) 2009-update 112; 2010.

4. Chen X, Chughtai AA, Dyda A, MacIntyre CR. Comparative epidemiology of Middle East respiratory syndrome coronavirus (MERS-CoV) in Saudi Arabia and South Korea. Emerg Microbes Infect. 2017;6(1):1-6. doi:10.1038/emi.2017.40

5. MacIntyre CR, Chughtai AA, Seale H, Richards GA, Davidson PM. Respiratory protection for healthcare workers treating Ebola virus disease (EVD): are facemasks sufficient to meet occupational health and safety obligations? Int $J$ Nurs Stud. 2014;51(11):1421. doi:10.1016/j.ijnurstu.2014.09.002

6. Zhong B-L, Luo W, Li H-M, et al. Knowledge, attitudes, and practices towards COVID-19 among Chinese residents during the rapid rise period of the COVID-19 outbreak: a quick online cross-sectional survey. Int J Biol Sci. 2020;16(10):1745. doi:10.7150/ijbs.45221

7. Chou R, Dana T, Buckley DI, Selph S, Fu R, Totten AM. Update alert 3: epidemiology of and risk factors for coronavirus infection in health care workers. Ann Intern Med. 2020;173(6):W123-W4. doi:10.7326/ L20-1005

8. Mayol J, Pérez CF. Elective surgery after the pandemic: waves beyond the horizon. Br J Surg. 2020;107(9):1091-1093. doi:10.1002/ bjs. 11688 
9. Brindle ME, Gawande A. Managing COVID-19 in surgical systems. Ann Surg. 2020;272(1):e1-e2. doi:10.1097/SLA.0000000000003923

10. Jessop ZM, Dobbs TD, Ali SR, et al. Personal Protective Equipment (PPE) for Surgeons during COVID-19 pandemic: a systematic review of availability, usage, and rationing. $B r \quad J$ Surg. 2020;107 (10):1262-1280. doi:10.1002/bjs. 11750

11. Chowdhury R, Luhar S, Khan N, Choudhury SR, Matin I, Franco OH. Long-term strategies to control COVID-19 in low and middle-income countries: an options overview of community-based, non-pharmacological interventions. Eur $J$ Epidemiol. 2020;35 (8):743-748. doi:10.1007/s10654-020-00660-1

12. Pakistan Ministry of Health. COVID-19 statistics; 2020 [cited October 15, 2020]. Available from: http://covid.gov.pk/stats/pakistan. Accessed October 10, 2020.

13. Asian Pacific. Virus cases among Pakistan's medical workers increase; 2020 [cited 202015 October]. Available from: https:// www.aa.com.tr/en/asia-pacific/virus-cases-among-pakistans-medicalworkers-increase/1826007. Accessed March 5, 2021.

14. American College of Surgeons. Clinical Issues and Guidance: internet source; 2020 [cited September 20, 2020]. Available from: https:// www.facs.org/covid-19/clinical-guidance. Accessed March 5, 2021.

15. Royal College of Surgeons. COVID-19: good practice for surgeons and surgical teams: internet source; 2020 [cited September 20, 2020]. Available from: https://www.rcseng.ac.uk/standards-and-research /standards-and-guidance/good-practice-guides/coronavirus/covid-19good-practice-for-surgeons-and-surgical-teams/. Accessed March 5, 2021.

16. Ministry of National Health Services, Regulations and Coordination. COVID-19 GUIDELINES; 2020 [cited October 20, 2020]. Available from: http://www.nhsrc.gov.pk/Detail/ NWYyMzg2MGMtM2ZmOC00YThlLTgyZmMtN2QxYTZjMjE3 YzQz.

17. Center for Disease Control and Prevention. Interim infection prevention and control recommendations for healthcare personnel during the Coronavirus disease 2019 (COVID-19) pandemic; 2020 [cited October 15, 2020]. Available from: https://www.cdc.gov/corona virus/2019-ncov/hcp/infection-control-recommendations.html. Accessed March 5, 2021.
18. Eysenbach G. Improving the quality of web surveys: the checklist for reporting results of internet e-surveys (CHERRIES). $J$ Med Internet Res. 2004;6(3):e34. doi:10.2196/jmir.6.3.e34

19. Agha R, Abdall-Razak A, Crossley E, et al. STROCSS 2019 guideline: strengthening the reporting of cohort studies in surgery. Int J Surg. 2019;72:156-165. doi:10.1016/j.ijsu.2019.11.002

20. Center for Disease Control and Prevention. Guidance for U.S. healthcare facilities about Coronavirus (COVID-19); 2020 [cited October 15, 2020]. Available from: https://www.cdc.gov/coro navirus/2019-ncov/hcp/us-healthcare-facilities.html. Accessed March $5,2021$.

21. German Society for Surgery. Guidelines for surgery; 2020 [cited October 15, 2020]. Available from: https://www.dgch.de/index.php? id=80. Accessed March 5, 2021.

22. World Bank. Data for middle income, Pakistan;2020 [cited October 20, 2020]. Available from: https://data.worldbank.org/?loca tions $=$ XP-PK. Accessed March 5, 2021.

23. Governoment of Pakistan Finance Division. Function-wise expenditure;2020 [cited October 20, 2020]. Available from: http:// www.finance.gov.pk/budget/Budget_in_Brief_2020_21_English.pdf. Accessed March 5, 2021.

24. Barenghi L, Barenghi A, Gianni A. Problems on going during the application of guidelines for COVID-19 prevention in dentistry. EC Dent Sci. 2020;19:79-88.

25. Tan L, Kovoor JG, Williamson P, et al. Personal protective equipment and evidence-based advice for surgical departments during COVID-19. ANZ J Surg. 2020;90(9):1566-1572. doi:10.1111/ ans. 16194

26. Saqlain M, Munir MM, Ur Rehman S, et al. Knowledge, attitude, practice and perceived barriers among healthcare professionals regarding COVID-19: a Cross-sectional survey from Pakistan. J Hosp Infect. 2020;105(3):419-423. doi:10.1016/j.jhin.2020.05.007

27. Jones NR, Qureshi ZU, Temple RJ, Larwood JP, Greenhalgh T, Bourouiba L. Two metres or one: what is the evidence for physical distancing in covid-19? BMJ. 2020;370:370. doi:10.1136/bmj.m3223
Journal of Multidisciplinary Healthcare

\section{Publish your work in this journal}

The Journal of Multidisciplinary Healthcare is an international, peerreviewed open-access journal that aims to represent and publish research in healthcare areas delivered by practitioners of different disciplines. This includes studies and reviews conducted by multidisciplinary teams as well as research which evaluates the results or conduct of such teams or healthcare processes in general. The journal

\section{Dovepress}

covers a very wide range of areas and welcomes submissions from practitioners at all levels, from all over the world. The manuscript management system is completely online and includes a very quick and fair peer-review system. Visit http://www.dovepress.com/testimonials. php to read real quotes from published authors. 